\title{
ЯЗЫКОЗНАНИЕ
}

\section{О функционировании лексемы цаг 'время' (на материале калмыцкого героического эпоса «Джангар»)}

\section{Нина Михайловна Мулаева}

\author{
${ }^{1}$ Калмыцкий научный центр РАН (д. 8, ул. И. К. Илишкина, Элиста 358000, Российская \\ Федерация) \\ кандидат филологических наук, научный сотрудник \\ iD 0000-0001-8395-849X. E-mail: mulaevanm@kigiran.com \\ (C) КалмНЦ РАН, 2020 \\ (C) Мулаева Н. М., 2020
}

Аннотация. Данное исследование является продолжением работ, в которых апробируются материалы Толкового словаря языка калмыцкого героического эпоса «Джангар». Цель работы состоит в рассмотрении роли и функции, а также в дефиниционном анализе лексемы цаг 'время', включенной в словник Толкового словаря. Материалом исследования послужили 28 текстов разновременных записей калмыцкого героического эпоса «Джангар». Результаты. Анализ лексемы ияа на материале эпических текстов дает основание называть ее ядерной лексемой или гиперонимом темпоральной лексики «Джангара». Лексема цаг является наиболее частотной из темпоральных лексем, зафиксированных в текстах эпоса «Джангар». В эпических текстах выявлено одиннадцать значений заголовочного слова цуа для Толкового словаря эпоса, которые в основном функционируют в устойчивых сочетаниях, в том числе и с другими темпоральными лексемами. Слово цаг обладает обширной сочетаемостью с лексемами, относящимися к различным частям речи и в составе устойчивых сочетаний приобретающими разные значения. В эпосе лексема цаг встречается в устойчивых сочетаниях арзин сүҮр бәрх изаг 'время пира'; дәәни цуаг 'время военное', которые являются лингвокультурными концептами. Зафиксированы устойчивые сочетания лексемы цаг с другими элементами микрополей обозначения времени: природное время (зун 'лето', намр 'осень'); календарное время (сар 'месяц', жсил 'год'); суточное время (хонг 'сутки', өрүн 'утро', сө 'ночь', $Y \partial$ 'полдень'). Лексема цүаг употребляется в устойчивых сочетаниях с темпоральными наречиями, обозначающими: продолжительность действия или процесса (оньдин 'постоянно, всегда'); давность действия (кезәнә 'давно, в давнюю пору'); определенный период времени (маңһһдур 'завтра'). Чаще всего лексема цаг в текстах эпоса сочетается с глаголами движения, состояния, действия.

Ключевые слова: лексема, сочетаемость, калмыцкий язык, эпос «Джангар», толковый словарь, цаг 'время'

Благодарность. Исследование проведено в рамках государственной субсидии проект «Устное и письменное наследие монгольских народов России, Монголии и 
Китая: трансграничные традиции и взаимодействия» (номер госрегистрации: АААA-A19-119011490036-1)

Для цитирования: Мулаева Н. М. О функционировании лексемы цуаг 'время’ (на материале калмыцкого героического эпоса «Джангар») // Монголоведение. 2020. Т. 12. № 3. C. 481-496. DOI: 10.22162/2500-1523-2020-3-481-496

\title{
Functioning of the Lexeme tsag 'Time' Revisited: a Case Study of the Kalmyk Heroic Epic of Jangar
}

\author{
Nina M. Mulaeva ${ }^{1}$ \\ ${ }^{1}$ Kalmyk Scientific Center of the RAS (8, Ilishkin St., Elista 358000, Russian Federation) \\ Cand. Sc. (Philology), Research Associate \\ iD 0000-0001-8395-849X. E-mail: mulaevanm@kigiran.com
}

\author{
(C) KalmSC RAS, 2020 \\ (C) Mulaeva N. M., 2020
}

\begin{abstract}
The paper continues a series of works that test materials of the Kalmyk Heroic Jangar Epic Explanatory Dictionary. Goals. The work seeks to examine the role and functions, provide a definition analysis of the lexeme uac 'time' included in the wordlist of the Explanatory Dictionary. Materials. The paper analyzes a total of 28 temporally different Kalmyk Jangar epic texts. Results. The analysis of epic texts concludes the lexeme may be defined as core one, or hyperonym of Jangar epic temporal vocabulary, and is most frequently used throughout the narrative. Epic texts give rise to eleven meanings of the header word u̧a within the Explanatory Dictionary, basically in set expressions, including when paired with other temporal lexemes. The word uaz is characterized by extensive co-occurrence with lexemes related to different parts of speech that gain new meanings within set expressions. In the epic narrative, the lexeme uаг appears in such set expressions as арзин сүур бәрх ияаг 'feast time'; дәәни ияаг 'war time', both being linguocultural concepts. It also pairs with other elements of time-denoting microfields, namely: natural time (зун 'summer', намр 'autumn'); calendar time (сар 'month', жсил 'year'); time of day (хонг '24-hour period', өрүн 'morning', $с \theta$ 'night', $Y \partial$ 'noon'). The lexeme u̧а is also used in set expressions that include temporal adverbs denoting - duration of length or process (оньдин 'constantly, always'); remoteness of action (кезәнә 'long ago, in ancient times'); certain period (маңһһур 'tomorrow'). In most cases the lexeme uaz co-occurs with verbs of motion, action, state, and auxiliary verbs. Frequent enough are u̧az-stemmed expressions that denote age periods or other periods in lives of epic heroes or war horses.
\end{abstract}

Keywords: lexeme, co-occurrence, Kalmyk language, Jangar epic, explanatory dictionary, ųą 'time'

Acknowledgements: The reported study was funded by government subsidy — project name 'Oral and Written Heritage of Mongolic Peoples of Russia, Mongolia and China: CrossBorder Traditions and Interactions' (state reg. no. AAAA-A19-119011490036-1).

For citation: Mulaeva N. M. Functioning of the Lexeme tsag 'Time' Revisited: a Case Study of the Kalmyk Heroic Epic of Jangar. Mongolian Studies (Elista). 2020. Vol. 12. No. 3. Pp. 481-496. (In Russ.). DOI: 10.22162/2500-1523-2020-3-481-496 


\section{Введение}

Настоящее исследование является продолжением работ ${ }^{1}$, в которых апробируются материалы Толкового словаря языка калмыцкого героического эпоса «Джангар» (далее - ТСД), создаваемого на базе 28 текстов разновременных записей калмыцкого героического эпоса «Джангар», объединенных в репертуарные циклы или представленных отдельными песнями.

В современной лингвистике исследователи большое внимание уделяют изучению темпоральной или временной лексики. Так, например, на материале русского и монгольского языков темпоральная лексика изучена в работах Д. Алтанцэцэга [Алтанцэцэг 2008а; Алтанцэцэг 2008б]. Темпоронимы на материале калмыцкого героического эпоса «Джангар» рассмотрены в работах [Омакаева 2014; Омакаева, Салыкова 2016], базовый концепт «время» на материале калмыцкого фольклора в статьях: [Голубева 2006; Голубева 2013; и др.].

Н. Д. Арутюнова отмечает, что время в языке может быть представлено двумя моделями: в центре первой модели оказывается человек, течение его жизни и линия судьбы - это модель Пути человека; в центре второй оказывается ориентация на само время, движение природных веществ - это модель Потока времени [Арутюнова 1997: 53]. Е. Н. Широкова пишет, что время может быть «объективным» и «субъективным», «... объективное (физическое) время понимается как время, «измеряемое отрезками пути небесных тел», а субъективное (психологическое) время — это «время в восприятии, переживании и сознании человека» [Широкова 2010: 14]. На наш взгляд, время в эпосе представлено как объективное время, которое зависит от времени суток, от положения небесных тел, и субъективное время, которое выражается через непосредственное восприятие его человеком ${ }^{2}$. Цель работы заключается в рассмотрении роли и функции, а также в дефиниционном анализе лексемы цุа 'время' на базе эпических текстов, включенных в словник ТСД.

\section{Об этимологии лексемы цаг 'время'}

Ш. Цэцэнцогт этимон и смысл слова цаг связывает со словом цааз 'закон, запрет, запрещение' и темпорему цзаг называет исконно монгольской [Цэцэнцогт 1988: 2168]. Л. Г. Скородумова пишет, что ц̧аг - это производная от древнетюркской основы $c a q$ 'время, пора', которая имеет общее происхождение со словом цагаан 'белый’ [Скородумова 2004: 228]. Д. Алтанцэцэг считает, что в научной литературе нет достаточно убедительных данных об этимоне и первосмысле слова щุаг, как и других временных лексем; по мнению исследователя, этимологию темпорем можно изучить, если внимательно проследить за функционированием этих лексем в изучаемом памятнике [Алтанцэцэг 2008б: 126].

\section{Значения лексемы цаг в лексикографических источниках}

В работе «Опыт лингвистического исследования эпоса „Джангар“» выделено два значения лексемы циаг: время; период [Тодаева 1976: 469]. В «Калмыцко-русском словаре» 1977 г. издания зафиксированы следующие значения лексемы цุаг: 1) время, пора; 2) час; 3) часы [КРС 1977: 621-622]. В «Большом

\footnotetext{
${ }^{1}$ См. подробно публикации: [Бачаева 2015; Бачаева 2017; Куканова 2016; Куканова 2018; Мулаева 2015; Мулаева 2017; и др.].

${ }^{2}$ См. подробно: [Малинская 2013].
} 
академическом монгольско-русском словаре» это слово представлено в значениях: 1) время; период; 2) час; 3) часы; 4) в сочетании: погода, климат [БАМРС 2002: 243-244]. В Толковом словаре Б. Б. Манджиковой лексема цุаг приведена в значениях болзг; кем; изаг-болзг 'время, период'; в сочетании: ж⿻илин дөрвн цаг ' четыре времени года' [Манджикова 2002: 140]. Как видим, в приведенных выше двуязычных словарях зафиксированы основные значения этой лексемы: время, период, пора.

\section{Функционирование лексемы цаг в текстах эпоса «Джангар»}

Лексема цаг 'время’ (312) 3 является самой частотной по сравнению с другими ключевыми темпоральными лексемами: хонг 'сутки' (223), жсил 'год' (215), өдр ‘день' (124), сө ‘ночь’ (67) и др., зафиксированными в эпических текстах.

При составлении словарной статьи с заголовочным словом цзаг 'время' для ТСД нами были рассмотрены все иллюстративные примеры, в которых употребляется лексема цุаг ‘время’ в текстах эпоса, и на основе анализа выявлено одиннадцать значений, каждое из которых рассмотрим далее подробно. В таблицах приведены устойчивые сочетания и даны соответствующие иллюстративные примеры из эпических текстов.

\section{1. Цаг 'время'}

Как известно, существует много авторитетных словарей, где дано толкование значений слова время достаточно подробно. В этом ключе достаточно обоснованным представляется мнение О. Ю. Богуславской, составителя «Активного словаря русского словаря». Автор пишет: «Естественно ожидать (как и в других случаях обращения к основным понятиям языка), что словарное описание слова время и других основных слов этой группы натолкнется на целый ряд трудностей» [Богуславская 2011: 67]. По мнению исследователя, в своем основном значении время - это нетолкуемое понятие. Понятие времени выступает в толкованиях в первую очередь в виде словосочетаний 'отрезок времени' и 'момент времени' [Богуславская 2011: 67].

В ТСД в своем основном значении время лексема цзаг выделена нами как философское понятие: «филос. основная (наряду с пространством) форма существования бесконечно развивающейся материи» ${ }^{4}$ и, по-видимому, данная лексема употребляется в эпосе в следующих сочетаниях:

- мөңзкин цุаг ‘вечное время’: Үкл уга мөңкин цагт / Үрглжсднн Жаңһһрахн / Болдг бәəжс гинд. 'Где смерти нет в вечное время, / Всегда Джангаровы [люди] / жили, говорят' [ОБ: І $]^{5}$;

- цагин дөрвн дала“четыре океана времени’: Цаһан хадыг / Цәкүр болтл, гөвдәд, / Цагин дөрвн дала дәәвлтл, гөвдв, 'Бело-голубая скала / В щебень превратилась — так он бил, / Времени четыре океана всколыхнулись — так он бил’ [МД: III].

\footnotetext{
${ }^{3}$ В скобках указана частотность лексемы в эпических текстах.

${ }^{4}$ Для составления словарной статьи с заголовочным словом ияа 'время' и толкования его значений были использованы: Справочно-информационный портал «Грамота.ру» и Электронный ресурс словарей русского языка Slovari.ru, разработанный Институтом русского языка им. В. В. Виноградова РАН.

${ }^{5}$ Перевод текстов эпоса «Джангар» с калмыцкого языка на русский осуществлен авторами публикуемого многотомного «Свода калмыцкого фольклора», выполняемого Калмыцким научным центром РАН (ранее - КИГИ РАН), см. подробно: [Манджиева 2016; Манджиева 2017].
} 


\section{2. Цаг 'календарное время'}

Слово цุаг 'время' в устойчивых сочетаниях принимает значение «пора дня, недели, года и т. п., связанная с явлениями природы» ${ }^{6}$.

В этом значении лексема цุаг употребляется в эпосе в сочетаниях с темпоремами суточного времени: өрүн 'утро', сө 'ночь', $Y \partial$ 'полдень' и темпоральным маркером мац̧һдур 'завтра' и лексемой календарного времени ж⿻ил 'год’. В текстах эпоса не зафиксированы устойчивые сочетания с темпоральными наречиями эндр 'сегодня', өцклдүр 'завтра':

- мащ̧һдур өрүн нарн hархин ияагт 'завтра утром, в то время, когда взойдет солнце';

- манһһур өрүн нарн мандлхин цчагт 'завтра утром, в то время, когда засияет солнце';

- маңุhдур өрүн мандлгсн нарн hархин цุагт 'завтра утром, в то время, когда взойдет сияющее солнце';

- маңһһур үдин цุагт 'завтра во время полудня': Мацһдур удин цагт, / Алтн Шарһ дәәвлхдән күрхин ияагт, 'Завтра во время полудня, / В то время, когда у коня Алтан Шарги силы истощились’ [ЭО: VIII];

- маңһһуртан hал үдин цагт 'завтра ровно во время полудня': Эн баранд маң $\boldsymbol{h}$ дуртан / hал үдин цагт / Зүркн тагтын цаад бийд, / Зүмбл тагтын наад бийд, 'Если ты завтра, ровно во время полудня, / Не доедешь до предмета, что / Виднеется по ту сторону моста Зюркен, / По эту сторону моста Зюмбал’ [ОБ: I];

- маңһдур һаслџта һал үдин циагт 'завтра ровно во время печального полудня': Мацhдур / һаслцта hал удин цагт күизд, 'Завтра, / Ровно во время печального полудня, догоню [врага]' [ОБ: I];

- сө болгсн цаг 'время, когда наступила ночь': Сө болгсн цагт, / Дөрвн мөчднь / Ahp зандн hасиг / hазрт шувт шаahad, 'В то время, когда наступит ночь, / В четыре конечности его / Колья из агар-сандала вбив, / К земле пригвождай’ [БЦ: III];

- сө дүлин аңхун цаг 'время полуночной тиши';

- иргч жслнь орсн цаг “время, когда наступил следующий год’: Иргч ж⿻илнь орсн цагт, / Эзн нойн Жаңһһp / Төвин дөрвн хаани күүк һолсн ияагт, / Ном төгс хаани күҮк залжс, 'В то время, когда наступил следующий год, / В то время, когда владыка-нойон Джангар / Отверг дочерей четырех ханов материка, / Пожаловали ему в жены дочь Номо Тегюс-хана' [ЭО: Х].

Зафиксировано всего два устойчивых сочетания лексемы изаг с темпоремами зун 'лето', намр 'осень', которые входят в состав лексико-семантического поля «природное время»:

- зуни ияаг 'время лета': Үвл уга зуни цагт / Үрглжсдән Жаңһрахн / Болдг бәәжс гинд. 'Без зимы, во время [непрестанного] лета, / Всегда Джангаровы люди / живут, говорят' [ОБ: I];

- намрин сүл сард өвсни орадк мөңзгн цุаһан мөндр үндсндән буух иаг 'в последний месяц осени, во время, когда застывшая на верхушках трав серебристо-белая изморозь в их корни впитаться еще может': Намрин сүл сард / Өвсни орадк мөңгн цаһан мөндр / Үндсндән буух цагт, / Унһн бийнь / Улан жулу өөкән таслл уга hарч. 'В последний месяц осени, / В то время, когда застывшая на верхушках трав серебристо-белая изморозь / В их корни впитаться еще могла, / Жеребенок, / Сохранив лишь тонкий слой жира, отпущен был' [БЦ: III].

\footnotetext{
${ }^{6}$ См.: Справочно-информационный портал «Грамота.ру» [электронный ресурc] // URL: http://

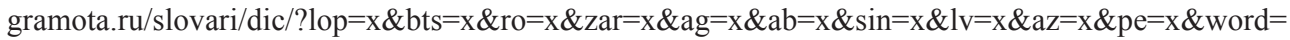
\%D0\%B2\%D1\%80\%D0\%B5\%D0\%BC\%D1\%8F (дата обращения: 10.01.2020).
} 


\section{Монголоведение • Mongolian Studies • $2020 \bullet$ T. 12 • № 3}

\section{3. Цаг 'относительное время'}

Устойчивые сочетания с лексемой цุаг могут принимать значение «момент или период и т. п., отведенные для чего-л., в которые происходит что-л.».

- арзин сүYр бәрх изаг 'время для проведения пира-арзы': Арзин изаһан өргә белн болв, / Арзин сүүр борх цаг болв, гижс / Алдр богд Жаңһртан / Дуудль тәвв гин. 'Богдо Джангар нойону: Белый дворец для арзы-пиршества готов, / Пришло время для проведения пира-арзы, сказав, / Славному богдо Джангару / Призыв-приглашенье отправили, говорят’ [ШД: V];

- арзин сүYр бәржс бәәсн цаг 'время, когда проводили пир-арзу';

- байн улан арзин сүҮр болад, суусн иаг, байн улан арзин сүҮр бәрәд бәәсн иуаг 'время пира, когда восседали за обильной красной арзой';

- балџ улан арзан сүҮрд суугсн цаг 'время пира, когда восседали за обильной ярко-красной арзой';

- дүҮвр хар арзин сүҮр болад, долан дуң̧һра күцәд суусн цагт 'в то время, когда, составив семь полных кругов, на пиру, за крепкой прозрачной арзой восседали’;

- арзин сүҮр тарсн циаг 'время, когда закончился (досл. разошелся) пир': Арзин сүур тарсн щагт, / Хоңһриг авхулад, / «Бәрнәв гигсн хааһан / Манд авч ир!» гижс зәрлг болв. 'В то время, когда закончился пир, / [Джангар] Хонгора подозвал: / - Хана, которого обещал ты пленить, / Доставь мне! — повелел’ [ЭО: ІІІ];

- асхн шүүсн болхин ияаг 'время перед вечерней трапезой': Асхи иүусн болхин цагт, / Әмд бирд көвүн нег ууц авч зулад, 'Во время перед вечерней трапезой, / Этот бирмен схватил целую ногу и стал убегать' [ЭО: IV];

- махан идх иаг 'время кушать мясо': Хаана күүкн махан идх / Цаг болад ирв. 'Настало время дочери хана кушать мясо’ [ШД: II];

- амрад-жсирһдд суусн цаг 'время, когда восседали в спокойствии и блаженстве';

- харhх иаг 'время встретиться’: Эн бидн хойр / Ода харhx цаг болвл билтәл! 'Нам с ним / Сейчас встретиться, видно, время настало’ [ЭО: VI];

- унтгсн цуаг 'время встретиться';

- хар нөөрин цаг 'время глубокого (досл. черного) сна': Асхндан дүувр хар нөөрин цагла күрч иртн. 'Вечером, во время глубокого сна [его] приходите' [ЭО: IX];

- тер циагт 'в тот момент': Балр хар шавр харhх. / Tep цагт Улман Агсг Уланан ТҮрүнд тәвтн, / Эврән меджс hарх. 'Встретится вам непроходимая топь. / В тот момент Аксак Улана пустите вперед, / Сам узнает, выведет [вас]’ [ЭО: IV].

В текстах эпоса очень часто встречаются устойчивые сочетания с лексемой цаг, в которых указывается на время, являющееся определенным периодом, этапом в жизни эпического героя или скакуна, поэтому можно выделить это значение отдельно. В фольклористических исследованиях такие временные моменты обозначаются термином биографическое время [Селеева 2011: 174]. В этом значении лексема изаг 'время' в переводах иллюстративных примеров может быть заменена лексемой пора, период.

- бийм hарад уга иагт 'в то время, когда сам я еще не был рожден': Бийм hapad уга цагт, / Ар Бумбин орим довтлжс авад, 'В то время, как сам я еще не был рожден, / В Ара Бумбайскую страну мою вторгся’ [МД: III];

- кезәнд, тана орнд орж⿻ өгәд уга изагт 'давно, в ту пору, когда я не был подвластен вашей стране';

- эзн нойн Жаңһр Төвин дөрвн хаани күүкд һолсн цагт 'в то время, когда владыка-нойон Джангар отверг дочерей четырех ханов материка'; 
- xamblhaн авх иагт 'в то время, когда брал в жены';

- эрт урд эзн Жаңһһр эн Гернзлән авх иұагт 'давно, раньше, в то время, когда владыка Джангар свою Герензел брал в жены';

- Жаңһһрин арвн зурһата Шавдльг залх ияат 'в то время, когда взял в жены Джангар шестнадцатилетнюю Шавдал';

- һазрин нег өнигт нойн болад бәәсн ияагт 'в то время, когда был нойоном одного уголка земли';

- хәрин маңุhсин ориг даргсн цагт 'в то время, когда покорил страну враждебных мангасов';

- алтн баран шар ицоохр армин хури цчагт 'в ту пору, когда острым было его боевое золотисто-пестрое копье’: Арнзл Зеердин хурдн цагт, / Алтн баран иар цоохр армин хурц цагт, / Эврә бийни баһ дүҮвр изагт / Төвин дөрвн хаани / Дөчн йисн нутгин күүкд һолад / Нарн һарх үд хойрин хоорнд бәәдг / Ном Төгс хаани күҮк / Арвн зурhата ah Шавдлыг авч ирсн, 'В ту пору, когда быстрым был его Аранзал Зээрде, / В ту пору, когда острым было его боевое золотисто-пестрое копье, / А сам был юн и удал, / Отвергнув девушек сорока девяти владений / Четырех ханов Тиба, / Шестнадцатилетнюю Шавдал привез [в жены]' [ЭО: I];

- ээж⿻ аав хойрнь орчлцзгин йосар өңзгрх цагт 'в то время, когда его отец и мать находились при смерти': Ээюс аав хойрнь / Орилцгин йосар / Өңгрх цагтан / «Долан үйәсн нааран көдләд уга / Догшн Хар Кинзинд оч түшич!» гивл. 'В то время, когда находились при смерти / Его отец и мать, по обычаю / Дали ему совет: / «Поезжай к Свирепому Хара Кинизу, примкни к нему, / Который с седьмого поколения не затевал войн»' [БМ: I];

- кезәнә Арнзл Зеердин хурдн ияагт 'давно, в ту пору, когда Аранзал Зеерде был резв’: Кезәнә Арнзл Зеердин хурдн цагт, / Таниг бөкнән иуглулад уга изагт, / Аля дүҮвр кеж / Эжсго эрм изаһан теегт йовсн изагтм... 'В давнюю пору, в то время, когда Аранзал Зээрде был резв, / Когда всех вас я еще не собрал, / Проявляя удаль свою, / В то время, когда по безлюдной пустынной степи я разъезжал' [ЭО: IV];

- күлг болгсн цагт 'в то время, когда стал скакуном'.

\section{4. Цаг мн.: 'времена' (период, эпоха в жизни)}

Лексема цุаг употребляется и в значении времена (период, эпоха в жизни человечества, какого-л. народа, государства, общества и т. п.), в этом значении можно выделить устойчивые выражения дән болсн изаг 'военное время' (досл. время, когда идут войны), встречаются сочетания тунхн ияаг 'время беспечности', эн цุаг 'наше время':

- тунххн ияаг 'времена беспечности': Эн Бумбин орни туцхн цагт алдулгсн / Эзн нойн Жаңһр нег юмнд күрәд чигнн уга. 'Из этой Бумбайской державы во времена ее / беспечности исчезнувший / Государь нойон Джангар все еще пристанища не обрел' [МД: ІІІ];

- дәәни ияаг (дән болсн ичаг) 'время военное': Шар Бирмс хаана нутгиг / Дәәләд орулад авхнь эн болв гинд. / «Маңһс, чаңһ, чиирг тоотан / Дәәни цагт өгит!» гивл. 'Так владение хана Шара Бирмиса / Покорили, говорят. / Самых сильных и крепких мангасов / В военное время доставляйте! — повелели [им]' [БМ: ІІ]; Эзн богд Жаңһр келв: / Дән болсн цагт, / Маңһс, чиирг тоотан өгчə! 'Владыка богдо Джангар сказал: / Доставляй [нам] во время войн / Самых сильных, самых крепких [воинов]' [БМ: V];

- эн циаг 'наше время': Эн цага күн болад, / Нанла хальдхнь / Яһна, тер улс! 'Будь они людьми нашего времени, / Пусть бы схватились со мной / Те люди’ [ЭО: I]. 


\section{5. В устойчивых сочетаниях: начальное раннее время}

В эпосе «Джангар» мифологическое начальное время передается чаще всего в устойчивом выражении эртни(н) (эртин) экн цุаг, один раз употребляется в сочетании с темпоральным наречием (наречием времени) кезәнә 'давно, в давнюю пору' и в фольклорном клише нег ц̧агин аңһхнд 'с самого начала (незапамятных) времен' в сочетаниях с глаголами.

- эртни(н) (эртин) экн цаг ‘раннее начальное время’: Эртнин экн цагт, /Эн олн бурхдын шажсн тогтх цагт һарсн, / Тәк Зула хаани үлдл, 'В начале ранних времен, / Во времена распространения веры бурханов родился / Потомок Таки Зула-хана' [ЭО: I];

- эрднин экн цаг 'драгоценное начальное время';

- олн бурхдын шажсн тогтх (делгрх) изаг 'время, когда расцветала вера многих бурханов';

- эж⿻го көдә ияаг 'безлюдья пустынного мира время': Эртни экн цагт, / Эжсго көдә цагт, / Дордын долан ор / Номдан орулад, / Күлг мөрн мини зовж,, '[Некогда], в изначальные времена, / Во времена безлюдья пустынного мира / Низлежащие семь миров / В веру свою обратив, [покорил я]. / Скакун мой кюлюк был изможден' [МД: II];

- кезәнд, эрт ияагт 'давно, в раннее время': Кезәнә, эрт цагт, / Жаңһрин арвн зурһата / Шавдлыг залх ияагт, 'Давно, в ранние времена, / В то время, когда Джангар брал в жены шестнадцатилетнюю Шавдал’ [ЭО: IV];

- нег ияагин анхнд төвкнх 'с начала [незапамятных] времен в покое пребывать': Эн Бумбин орн нег цагин аңхнд / Төвкнгсн бәәдг. 'Эта Бумбайская держава с самого начала времен / В покое пребывает’ [МД: III];

- нег ияагин аңхнд уняртх 'с самого начала времен виднеться в мареве';

- нег цагин аңухнд дүңгәх 'с начала [незапамятных] времен величественно простираться': Көгшн Ширкин әңзг / Нег цагин аңхнд / Дүңгәгсн бәәдг. 'Старца Ширкея владения / С начала [незапамятных] времен / Величественно простираются’ [МД: ІІІ].

\section{6. В сочетаниях: возраст (человека или животного)}

Лексема цุаг ‘время’ в устойчивых сочетаниях обозначает какой-либо возрастной период в жизни человека или животного. По отношению к человеку эти устойчивые сочетания чаще всего употребляются со словом насн 'возраст'. Устойчивые сочетания, обозначающие возраст эпического героя:

- эркән дүңгә цаг ‘возраст (время), когда величиной с большой палец’: Эркән дүңгә цагтнь / Ээжс аав хойраһинь / Эрлг авч энлүлгсн, 'В возрасте, когда величиной с большой палец он был, / Его отца и мать / Прибрал эрлик, [заставив] его мучиться' [БМ: V];

- эркән дүнгә hунн наста цุаг 'трехлетнего возраста, величиной с большой палец время’: Эркән дүцгә һунн наста цагтан / Буйн төгс ааван / Буй уга оркад, / Бумба герл ээжсән / Көвүн уга оркад, 'В трехлетнем возрасте, когда величиной с большой палец он был, / Добродетельного отца своего / Без почтения оставив, / Бумбайскую светлой души мать свою / Без сына оставив' [БЦ: ІІІ];

- баһ дүувр изаг 'юное удалое время (возраст)';

- һунн наста цаг 'трехлетнего возраста время': Аңхн түрунд, чини һунн наста цагт, / Эик чинь, ҮҮзй Мала алдр хан, / Армичн надар кегүлхдән, ‘Давно, когда ты был в трехлетнем возрасте, / Отец твой, Узюнг Мала, славный хан, / Твое копье мне заказывал' [БЦ: І]; 
- дөнн наста цаг 'четырехлетнего возраста время';

- тавн наста цаг 'пятилетнего возраста время';

- долата цаг 'время, когда было семь (лет), семилетний возраст';

- долан наста изаг 'семилетнего возраста время’: Долан наста цагтан / Долан орнд хурдарн һаргсн / Көк Һалзн күлгтә гинә 'В семилетнем возрасте / В семи странах резвостью своей прославившийся / Кеке Галзан - скакун его, говорят' [БЦ: I].

Ниже приведем устойчивые сочетания с лексемой цุаг, обозначающие возраст скакуна:

- сарва цุаг 'годовалое время (о жеребенке)': Сәәхн Күрң мөриһән сарва цагтнь / Сай мөңзгәр хулджс авад 'Свою прекрасную кобылицу Кюрюнг еще стригунком / За миллион монет купив’ [БЦ: I];

- сарва баһ цаг 'годовалое раннее время (о жеребенке)': Чамаг сарва баһ цагтчн, / Сай өркәр сән болх гижс, / Юуни төлә авлав? 'Тебя в годовалом раннем возрасте / За миллион семей, надеясь, что станешь лучшим из [скакунов], / Ради чего я взял' [ЭО: VIII];

- сарва даaһн цаг 'двухгодовалое время (о жеребенке, лончаке)': Сәәхн Күрң мөрән / Сарва дааһн цагтнь / Сай мөңгәр хулджс авад, 'Свою прекрасную кобылицу Кюрюнг, / Стригунком еще / За миллион монет купив’ [БЦ: III];

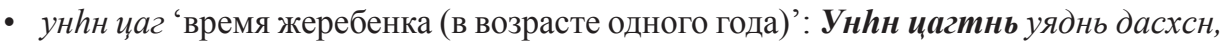
/ Дааһн цагтнь дәәни көлд дасхсн, / Үрә цагтнь / Уйн зандн арманнь мартлинд дасхгсн, / Дөнн цагтнь / Дуут Жаңһр хан күлглгсн, / Дугтргсн хурдн Зеердтә ... 'В возрасте одного года к привязи он был приучен, / В двухгодовалом возрасте к походам был приучен, / В трехгодовалом возрасте / К битвам и сражениям был приучен. / На четвертом году [жизни] / Славный Джангар стал ездить верхом / На проворном резвом Зээрде' [БМ: І];

- даaһн цаг 'время двухгодовалого жеребенка';

- үрә цаг 'трехгодовалое время';

- дөнн циаг 'четырехлетнее время'.

\section{7. В устойчивых сочетаниях: большую протяженность пространства или продолжительность действия}

В текстах эпоса категориальные понятия времени и пространства связаны воедино, ведь эпический герой обычно находится много времени в пути, преодолевая большие пространства.

Лексема цุаг в повторяющихся эпических формулах обозначает:

1) большую протяженность пространства (кесг цุагт йовх 'много времени ехать');

2) продолжительность действия (кесг цүагт чавчлдх 'много времени рубиться').

Самыми частотными являются устойчивые глагольные сочетания лексемы изаг с наречием кесг 'много':

\footnotetext{
${ }^{7}$ Стригунок - годовалый жеребенок, которому обычно подстригают гриву (см.: Электронный ресурс словарей русского языка, разработанный Институтом русского языка им. В. В. Виноградова РАН [электронный ресурс] // URL: slovari.ru // http://www.slovari.ru/search.aspx?s=0\&p=3068 (дата обращения: 10.01.2020)).
} 
- движения (йовх 'ехать’, гүYX ‘бежать', гүYлгх ‘скакать; мчаться’, хурдлх 'мчаться’, хурдлулх ‘ускорять, убыстрять', көтлх ‘вести на поводу’, зҮҮлх ‘блуждать');

- состояния (унтх 'спать');

- действия (чавчлдх 'рубиться').

В этих эпических формулах употребляется и темпоратив $Y и ̆$ 'период’.

- кесг ияагтан, кесг үйдән йовх 'много времени, много периодов ехать': СУУр көндрәд, / Күр-күр гиһдд, / Кесг цагтан, кесг үйдән йовад, / Авлңһин хаана / Отгинь нег захарнь / Орад күрж⿻нндд ирнд. 'Все отправились в [поход] / С шумом, / Много времени, много периодов ехали, / Авланги хана / В пределы отока / Въехали с шумом’ [ОБ: I];

- кесг чигн ияагтан гүүһдд йовх 'много времени бежать';

- кесг цагт хурдлад оркх 'много времени мчаться': Арнзльгн Зеерд кесг цагт / Хурдлад оркв, 'Аранзал Зээрде много времени / Мчался’ [МД: II];

- кесг цагтнь хурдлулад оркх 'много времени ускорять';

- кесг цагтан көтләд одх 'много времени вести на поводу';

- кесг цагтан, кесг үйдән, долан-долан дөчн йисн хонгтан гүҮлгх 'много времени, много периодов, семью семь - сорок девять суток скакать': Кесг цагтан, / Кесг үйдән, / Долан-долан / Дөчн йисн хонгтан / Гүүлгхо, / Күцсәр күрч йовад, / Өмннь хәәкрнә: / Көвүн, зогс! 'Много времени, / Много периодов, / Семью семь — / Сорок девять суток / Проскакал он [на коне]. / Настигая [щулмуса], / Перед ним крикнул: / Юноша, остановись' [ОБ: I];

- кесг иагтан гүҮлгх, кесг үйдән зүүлх 'много времени мчаться, много периодов блуждать’: Кесг цагтан гүүлгәд, / Кесг үйдән зүүләд, / Баатр Жаңһрин орар орад ирв. 'Много времени мчались, / Много периодов блуждали, / Богатыря Джангара в страну вступили они' [МД: II];

- кесг ияагтан унтх 'много времени спать': Сур мет сунад, / Суха мет улаһад, / Терүндән кесг цагтан / Унтад окдг болна. Уснул он, / Растянувшись, как ремень, / Раскрасневшись как тамариск. / Много времени / Он спал’ [ОБ: I];

- hурвн сара hазрт гүҮлгсн цуаг 'время, когда три месяца проскакал': Дәкн һурввн сара hазрт гүүлгсн цагт, / Өл Маңхн Цаһан уулын ора харһад ирв. 'В то время, когда еще трехмесячный путь проскакал [на коне], / Показалась вершина дымчатой горы Мангхан Цаган’ [ЭО: Х];

- долан хонгт гүүлгсн цаг 'время, когда проехал семь суток'.

\section{8. В сочетании с числительным дөрвн 'четыре времени (года)'}

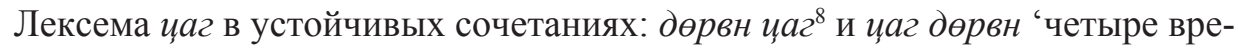
мени (года)' носит значение времена года «периоды, на которые делится год в соответствии с видимым движением солнца по небу и изменениями, происходящими в природе (весна, лето, осень, зима)» и употребляется в повторяющихся эпических формулах, где в качестве компонента устойчивых именных словосочетаний число четыре обозначает единицу традиционного фольклорно-эпического членения предметов [Пюрбеев 2015: 84]:

- оньдин дөрвн изагт 'всегда в четырех временах (года)': Бәрдг эзнднь / Оньдин дөрвн цагт / Өлзәнь күртәд йовдг / Догшн хар бәрңкиг, 'Владельцу его / Всегда

\footnotetext{
${ }^{8}$ Словосочетание дөрвөн цаг в монгольском языке означает и 'четыре часа', и 'четыре времени года' [Пюрбеев 1984: 42].
} 
в четырех временах [года] / Удачу приносящий / Свирепый черный бяренки' [ШД: V];

- мөңък (мөнукән) дөрвн цаг 'вечные четыре времени (года)': Эзн Жаңһһрин эврәннь услурнь / Киитн Домб гидг һолнь / Мөцкән дөрвн цагт / Көрл уга бәәдг гинд. 'Сам владыка Джангар пьет / Из студеной реки Домбо, / В вечные четыре времени [года] / Не замерзает [она], говорят’ [БЦ: I];

- аль дөрвн цагт 'в любых (всяких) четырех временах (года)': Зүудн болгсн богд Жаңһрр хан / Үрглжсд һучн һурвн теңзгрин ж⿻ирһлиг / Алдл уга, аль дөрвн цагт / Сәәхн жсирһв. 'Прекрасный, как сон, богдо хан Джангар, / Тридцати трех тенгриев блаженство / Испытывая, в любые четыре времени [года] / Счастливо жил' [БЦ: ІІ];

- цаг дөрвн хүҮв болх 'в четырех временах (года) пребывать’: «Хатлгсн хатнь ямр болхв?» гиһдд, / Аль дөрвн нутг дунд / Цаг дөрвн хүУв болсар бәәдг санжс. 'Какова же супруга ханша его? / Посреди четырех нутуков / В четырех временах [года] пребывает’ [ШД: V].

\section{9. В сочетании с наречием хамm: одновременно}

Один раз лексема цзаг употребляется в сочетании с наречием хамm 9 (цаг xaмm 'досл. время совместно'), в контексте это сочетание приобретает значение одновременно (происходить, совершаться в одно и то же время):

- Тож Зандн дарһ, бәәнч? - гиһәд, / Дуудад оркв. / Долан миңһн мөрч / Эн дуунла цаг хамm / Шар-иоохр бәәшигин Үүднд / Нег агчмд иуглрв. 'Тоджи Зандан дарга, здесь ли ты? - / Окликнул он. / На этот голос одновременно / Семь тысяч конюших / У дверей желто-пестрого дворца / Вмиг собрались’ [БЦ: І].

\section{0. В устойчивом сочетании эдҮ тедү болсн цагт 'спустя немного времени'}

Устойчивое сочетание эдү тедү болсн цұагт 'спустя немного времени' употребляется, когда речь идет о каком-л. неопределенном отрезке времени, в эпосе оно представлено в разных вариантах:

- эдY тедү болсн циагт 'когда некоторое (какое-то) время прошло': ЭдУ теду болгсн цагт / Эн өргәлсн хатнаснь көвүн һарвл. 'Прошло некоторое время / Супруга [Хонгора] родила сына' [БМ: II];

- эдү тедү болжс бәәсн цагт 'когда немного времени прошло';

- эдY тедү болад одсн цุагт 'когда немного времени прошло': Бас эдү-тедY болад одгсн цагт, / Нуурин көвәд бәәгсн / Көк дааһан хәләһәд, хәржс йовв. 'Еще немного / Времени прошло, / Пошел он проведать своего сивого жеребенка, который находился на берегу озера, / И вернулся обратно’ [ЭО: I].

\section{Употребление лексемы цаг во фразеологизированном сочетании}

Один раз употребляется фразеологированное сочетание тав болгсн цагт 'то время, когда в ярости', когда речь идет об эпическом герое-богатыре. Следует отметить, что устойчивое выражение тав болх 'выстояться', в текстах эпоса зафиксировано лишь в тех примерах, где дается характеристика скакуну:

${ }^{9}$ Хамт 'вместе, совместно; сообща; воедино' [КРС 1977: 573]. 


\section{Монголоведение • Mongolian Studies • $2020 \bullet$ T. 12 • № 3}

Һо зандни йозурт / Һолшг улан элснд / Долан хонг уйв. / Арнзльн Зеерд тав болад ирв. / Тав болсн кемжзәнь / Ямаран гихнь: / Сән бийән / Сәәр талан авад, / Сәәхн бийән / Чеежс талан авад, Хурдн бийән / Дөрвн хар /Турун талан авад, 'У корней стройного сандала, / В нежном красном песке / На семеро суток привязал он [скакуна]. / Из аранзалов [лучший], Зээрде полностью выстоялся. / Полной выстойки приметы / Каковы, если спросить: / Силу-доблесть свою / В крупе собрал он, / Стать-красоту свою / В груди собрал он,/ Скорость-резвость свою / К четырем черным / Копытам своим подобрал он’ [МД: I];

Тав болсн Көк Һалзнарн одвл. 'На выстоявшемся Кеке Галзане промчался он' [БM: II].

В отношении богатыря это выражение применено, чтобы описать его превосходные физические качества:

«Нарт делкән орнд / Чамла әдл баатр, чиирг» гинд, / «Тав болгсн цагтан, / Тавн түмн иергт / Һанцарн күч күрдг» гинд. 'На всем белом свете / Равный тебе богатырь и силач он, говорят, / В то время, когда в ярости / С пятью туменами войск / В одиночку способен расправиться он, говорят' [БЦ: І].

\section{Заключение}

Исследование лексемы цุаг ‘время’ на материале эпоса «Джангар» позволяет сделать следующие выводы:

- лексема изаг является ядерной и наиболее частотной из темпоральных лексем, зафиксированных в текстах эпоса «Джангар»;

- в эпических текстах выявлено 10 значений заголовочного слова цаг для Толкового словаря эпоса, которые в основном раскрываются в устойчивых сочетаниях, в том числе и с другими темпоральными лексемами;

- слово цุаг обладает обширной сочетаемостью с лексемами, относящимися к различным частям речи и в составе устойчивых сочетаний приобретающими разные значения;

- в эпосе лексема цаг встречается в устойчивых сочетаниях арзин сүҮр бәрх изаг 'время пира'; дәәни цุаг 'время военное';

- зафиксированы устойчивые сочетания лексемы цаг с другими элементами микрополей обозначения времени: природное время (зун 'лето', намр 'осень'); календарное время (сар 'месяц', жсил 'год'); суточное время (хонг 'сутки', өрүн 'утро', сө 'ночь', $ү \partial$ 'полдень');

- лексема цуаг употребляется в устойчивых сочетаниях с темпоральными наречиями, обозначающими: продолжительность действия или процесса (оньдин 'постоянно, всегда'); давность действия (кезәнә 'давно, в давнюю пору'); определенный период времени (мащ̧һдур 'завтра');

- чаще всего лексема цุаг в текстах эпоса сочетается с глаголами движения, состояния, действия и со вспомогательными глаголами (бәәх, болx);

- частотны устойчивые сочетания с лексемой цุаг, которые обозначает возрастной период или какой-либо период в жизни эпического героя или скакуна. 


\section{Источники}

БМ - цикл песен из репертуара Басңһа Мукөвүн (Мукебена Басангова)

БЦ - Багацохуровский цикл

МД - Малодербетовский цикл

ОБ - песня из репертуара Овшин Бадм (Бадмы Обушинова)

ШД - цикл песен из репертуара Давы Шавалиева

ЭО — цикл песен из репертуара Ээлян Овла

Baya Dorbet (Jangar Epic) Cycle. (In Kalm.)

Baya Tsokhor (Jangar Epic) Cycle. (In Kalm.)

Cycle of Songs Recorded from Dava Shavaliev (Shavalin Dava). (In Kalm.)

Cycle of Songs Recorded from Eelyan Ovla (Ovla Eelyaev). (In Kalm.)

Cycle of Songs Recorded from Mukeben Basangov (Basyya Mukövün). (In Kalm.)

Song Recorded from Badma Obushinov (Ovshin Badm). (In Kalm.)

\section{Литература}

Алтанцэцэг 2008а - Алтаниэџээ Д. Именная темпоральность в картине мира русского и монгольского языков (на материале памятников письменности и народных календарей): автореф. дисс. ... канд. филол. наук. Казань, 2008. 23 с.

Алтанцэцэг $2008 б$ - Алтаниэиэг Д. Синкретизм временной лексики как отражение целостности мира в древнемонгольском языке (на материале «Сокровенного сказания монголов») // Вопросы когнитивной лингвистики. Тамбов: Российская ассоциация лингвистов-когнитологов, 2008. № 3 (016). С. 125-128.

Арутюнова 1997 - Арутюнова Н. Д. Время: модели и метафоры // Логический анализ языка. Язык и время / отв. ред. Н. Д. Арутюнова, Т. Е. Янко. М.: Индрик, 1997. C. $51-62$.

БАМРС 2002 - Большой академический монгольско-русский словарь в 4-х томах / отв. ред. Г. Ц. Пюрбеев. Т. 4. Х-Я. М.: Academia, 2002. 532 с.

Бачаева 2015 - Бачаева С. Е. Лексическая сочетаемость имен прилагательных, обозначающих размер и величину (на материале песен эпоса «Джангар» и Национального корпуса калмыцкого языка) // Актуальные проблемы современного монголоведения. Элиста: КИГИ РАН, 2015. С. 103-115.

Бачаева 2017 - Бачаева C. E. Толковый словарь языка калмыцкого героического эпоса «Джангар»: дефиниции, обозначающие возраст // Вестник НИИ гуманитарных наук при Правительстве Республики Мордовия. 2017. № 4 (44). С. 170-178.

Богуславская 2011 - Богуславская О. Ю. Лексикографические проблемы описания временной лексики // Сб. статей к 80-летию акад. Ю. Д. Апресяна. М.: Языки славянских культур, 2011. С. 66-78.

Голубева 2006 - Голубева Е. В. Национально-культурная специфика картины мира в калмыцком языке (на примере культурных концептов): автореф. дисс. ... канд. филол. наук. М., 2006. 25 с.

Голубева 2013 - Голубева Е. В. Базовый концепт «время» в калмыцком фольклоре // Современная филология: мат-лы II Междунар. науч. конф. (г. Уфа, 20-23 января 2013 г.). Уфа: Лето, 2013. С. 65-67.

Кичиков $1979-$ Кичиков А. Ш. Үгин туск үг (= Слово о словах). На калм. языке. Элиста: Калм. кн. изд-во, 1979. $101 \mathrm{c.}$

Куканова 2016 - Куканова В. В. Толковый словарь языка калмыцкого героического эпоса «Джангар»: принципы и проблемы составления словарных статей // «Джангар» и эпические традиции тюрко-монгольских народов: проблемы сохранения и исследования. Мат-лы III Междунар. науч. конф., посвящ. 75-летию Калмыцкого 
института гуманитарных исследований РАН (г. Элиста, 15-16 сентября 2016 г.). Элиста: КИГИ РАН, 2016. С. 7-12.

Куканова 2018 - Куканова В. В. Лексема билиг: к вопросу о происхождении и семантике (на материале эпоса «Джангар») // Oriental Studies. 2018. № 4. С. 100-121.

КРС 1977 - Калмыцко-русский словарь / под ред. Б. Д. Муниева. М.: Рус. яз., 1977. $768 \mathrm{c}$.

Малинская 2013 - Малинская Т. В. Темпоральные синтаксемы с лексемой заря // Вестник Московского государственного областного университета. 2013. № 6. С. 59-62.

Манджиева 2016 - Манджиева Б. Б. О создании базы данных аутентичных текстов калмыцкого героического эпоса «Джангар» // Монголоведение. Вып. 9. Элиста: КалмНЦ РАН, 2016. С. 211-217.

Манджиева 2017 - Манджиева Б. Б. К проблеме составления Свода калмыцкого фольклора // Языки и фольклор коренных народов Сибири. 2017. № 1 (32). С. 82-89.

Манджикова 2002 - Манджикова Б. Б. Хальмг келнә тәәлвр толь (сурһульчнрт нерәдсн дөңцл) (= Толковый словарь калмыцкого языка (пособие для учащихся)). Элиста: АПП «Джангар». 2002. 176 с.

Мулаева 2015 - Мулаева Н. М. Дефиниции растений в Толковом словаре языка калмыцкого героического эпоса «Джангар» // Урало-алтайские исследования. 2015. № 3 (18). C. 64-74.

Мулаева 2017 - Мулаева Н. М. Титульные лексемы хан, хаан, хатн в Толковом словаре языка калмыцкого героического эпоса «Джангар» // Монголоведение. Вып. 10. Элиста: КалмНЦ РАН, 2017. С. 5-16.

Омакаева 2014 - Омакаева Э. У. Темпоральная лексика в калмыцком героическом эпосе «Джангар» и проблемы ее лексикографического отражения // Вестник Калмыцкого института гуманитарных исследований РАН. 2014. № 4. С. 108-112.

Омакаева, Салыкова 2016 - Омакаева Э. У., Сальккова В. В. Типология номинаций суточного времени в зеркале эпических формул: на материале калмыцкого героического эпоса «Джангар» // Вестник Калмыцкого университета. 2016. № 3 (31). С. $62-68$.

Пюрбеев 1984 - Пюрбеев Г. Ц. Современная монгольская терминология: лексико-семантические процессы и деривация. М.: Наука, 1984. 120 с.

Пюрбеев 2015 - Пюрбеев Г. Ц. Эпос «Джангар»: культура и язык (= Жаңһр дуулвр: сойл болн келн) / на русском и калмыцком языках. 2-е изд., перераб. Элиста: НПП «Джангар», 2015. 280 с.

Селеева 2011 - Селеева Ц. Б. Динамические и статические свойства пространства и времени в калмыцком героическом эпосе «Джангар» // Вестник Калмыцкого института гуманитарных исследований РАН. 2011. № 1. С. 173-177.

Скородумова $2004-$ Скородумова Л. Г. Монгольский язык. Образы мира. Улаанбаатар, Бемби сан, 2004. 328 с.

Тодаева 1976 - Тодаева Б. Х. Опыт лингвистического исследования эпоса «Джангар». Элиста: Калм. кн. изд-во, 1976. 530 с.

Цэцэнцогт 1988 - Цэиэнцуогт Ш. Корневой словарь монгольских слов. Хөххот: Ардын хэвлэлийн хороо, 1988. 2972 с.

Широкова 2010 - Широкова $E$. Н. Темпоральный код языка и его эмотивный субкод: монография. Нижний Новгород: изд-во «Нижегородский гос. пед. ун-т», 2010. $189 \mathrm{c.}$

\section{References}

Altantsetseg D. Nominative Temporality in Russian and Mongolian Linguistic Worldviews: a Case Study of Written Monuments and Folk Calendars. Cand.Sc. (philology) thesis abstract. Kazan, 2008. 23 p. (In Russ.) 
Altantsetseg D. Syncretism of temporal vocabulary as a reflection of the world's integrity in Old Mongolian: a case study of The Secret History of the Mongols. Issues of Cognitive Linguistics. 2008. No. 3 (016). Pp. 125-128. (In Russ.)

Arutyunova N. D. Time: models and metaphors. In: Logical Analysis of Language. Language and Time. Arutyunova N. D., Yanko T. E. (eds.). Moscow: Indrik, 1997. Pp. 51-62. (In Russ.)

Bachaeva S. E. Explanatory Dictionary of the language of the Kalmyk heroic epic poem 'Jangar': definitions denoting the age. Vestnik NII gumanitarnykh nauk pri Pravitel'stve Respubliki Mordoviya. 2017. No. 4 (44). Pp. 170-178. (In Russ.)

Bachaeva S. E. Lexical co-occurrence of size-denoting adjectives: a case study of Jangar epic songs and Kalmyk National Corpus. In: Topical Issues of Contemporary Mongolian Studies. Elista: Kalmyk Humanities Research Institute of RAS, 2015. Pp. 103-115. (In Russ.)

Boguslavskaya O. Yu. Describing temporal vocabulary: lexicographic problems. In: Acad. Yu. D. Apresyan. Celebrating the $80^{\text {th }}$ Anniversary of Birth. Coll. articles. Moscow: Yazyki Slavyanskikh Kultur, 2011. Pp. 66-78. (In Russ.)

Golubeva E. V. A fundamental concept of time in Kalmyk folklore. In: Contemporary Philology. Conf. proc. (Ufa; January 20-23, 2013). Ufa: Leto, 2013. Pp. 65-67. (In Russ.)

Golubeva E. V. Ethnic and Cultural Specifics of the Kalmyk Linguistic Worldview: a Case Study of Cultural Concepts. Cand.Sc. (philology) thesis abstract. Moscow, 2006. 25 p. (In Russ.)

Kichikov A. Sh. A Word about the Word. Elista: Kalmyk Book Publ., 1979. 101 p. (In Kalm.)

Kukanova V. V. Kalmyk Heroic Jangar Epic Explanatory Dictionary: compiling dictionary entries - principles and problems. In: The Jangar and Epic Traditions of Turko-Mongols: Issues of Preservation and Research. Jubilee conf. proc. (Elista; September 15-16, 2016). Elista: Kalmyk Humanities Research Institute of RAS, 2016. Pp. 7-12. (In Russ.)

Kukanova V. V. The lexeme biltsg: etymology and semantics revisited (a case study of the Jangar epic). Oriental Studies. 2018. No. 4. Pp. 100-121. (In Russ.)

Malinskaya T. V. Temporal syntaxeme with the lexeme zarya. Bulletin of the Moscow State Region University. 2013. No. 6. Pp. 59-62. (In Russ.)

Mandzhieva B. B. On the creation of a database of authentic texts of the Kalmyk heroic epic 'Dzhangar'. In: Mongolian Studies. Vol. 9. Elista: Kalmyk Scientific Center of RAS, 2016. Pp. 211-217. (In Russ.)

Mandzhieva B. B. To the problem of drawing up the Kalmyk Folklore Corpus. Languages and Folklore of Indigenous Peoples of Siberia. 2017. No. 1 (32). Pp. 82-89. (In Russ.)

Mandzhikova B. B. Explanatory Dictionary of the Kalmyk Language. Schoolbook. Elista: Dzhangar, 2002. 176 p. (In Kalm.)

Mulaeva N. M. Definitions of plants in the explanatory dictionary of the language of the Kalmyk heroic epic 'Dzhangar'. Ural-Altaic Studies. 2015. No. 3 (18). Pp. 64-74. (In Russ.)

Mulaeva N. M. The title lexemes khan, khaan, khatn in the Definition Dictionary of the Kalmyk heroic epic of Jangar. In: Mongolian Studies. Vol. 10. Elista: Kalmyk Scientific Center of RAS, 2017. Pp. 5-16. (In Russ.)

Muniev B. D. (ed.) Kalmyk-Russian Dictionary. Moscow: Russkiy Yazyk, 1977. 768 p. (In Kalm. and Russ.)

Omakaeva E. U. Temporal lexis in the Kalmyk heroic epic Dzhangar and the issues of its lexicographic reflection. Bulletin of the Kalmyk Institute for Humanities of the RAS (Oriental Studies). 2014. No. 4. Pp. 108-112. (In Russ.)

Omakaeva E. U., Salykova V. V. Typology of nominations of daily time in the mirror of epic formulas: on the material of the Kalmyk heroic epic 'Dzhangar'. Bulletin of Kalmyk University. 2016. No. 3 (31). Pp. 62-68. (In Russ.) 
Pyurbeev G. Ts. (ed.)Unabridged Academic Mongolian - Russian Dictionary. In 4 vols. Vol. 4: X-Я. Moscow: Academia, 2002. 532 p. (In Mong. and Russ.)

Pyurbeev G. Ts. Contemporary Mongolian Terminology: Lexical-Semantic Processes and Derivation. Moscow: Nauka, 1984. 120 p. (In Russ.)

Pyurbeev G. Ts. Epic of Jangar: Culture and Language. $2^{\text {nd }}$ ed., rev. Elista: Dzhangar, 2015. 280 p. (In Russ. and Kalm.)

Seleeva Ts. B. Kalmyk heroic epic of Jangar: dynamic and static properties of space and time. Bulletin of the Kalmyk Institute for Humanities of the RAS (Oriental Studies). 2011. No. 1. Pp. 173-177. (In Russ.)

Shirokova E. N. Temporal Code of Language and Its Emotive Sub-Code. Monograph. Nizhny Novgorod: Minin Nizhny Novgorod State Pedagogical University, 2010. 189 p. (In Russ.)

Skorodumova L. G. Mongolian Language: View of the World. Ulaanbaatar: Bembi San, 2004. 328 p. (In Russ.)

Todaeva B. Kh. Epic of Jangar: a Linguistic Study. Elista: Kalmyk Book Publ., 1976. 530 p. (In Russ.)

Tsetsentsogt Sh. Dictionary of Mongolic Word Stems. Hohhot: Inner Mongolia People's Publ., 1988. 2972 p. (In Mong.) 